\title{
MODEL HIDROLIKA UNTUK SIMULASI PROFIL MUKA AIR PADA SUNGAI SIBINAIL KABUPATEN PASAMAN
}

\author{
Rizki Rianda Putra ${ }^{1}$, Manyuk Fauzi ${ }^{2}$, Sigit Sutikno ${ }^{3}$ \\ 1,2,3 Program Pasca Sarjana, Magister Teknik Sipil, Universitas Riau \\ Kampus Bina Widya JL. HR Soebrantas KM 12,5 Pekanbaru, Kode Pos 28293. \\ Email: rizki.rianda@student.unri.ac.id, manyuk.fauzi@unri.ac.id, sigit.sutikno@lecturer.unri.ac.id
}

\begin{abstract}
ABSTRAK
Sungai Sibinail di Kabupaten Pasaman merupakan salah satu sungai yang rawan mengalami bencana banjir. Untuk mengatasi masalah banjir tersebut diperlukan informasi mengenai kedalaman banjir dan titiktitik dimana lokasi yang rawan terhadap banjir. Oleh karena itu melakukan simulasi profil muka air bertujuan untuk memberikan suatu informasi mengenai kedalaman banjir dan titik rawan banjir pada Sungai Sibinail Kabupaten Pasaman. Pemodelan simulasi profil muka air menggunakan perangkat lunak HEC-RAS. Debit banjir rancangan dihitung dengan kala ulang 2 tahun, 5 tahun, 10 tahun, 25 tahun dan 50 tahun menggunakan hidrograf satuan sintetik (HSS) gama I . Kondisi batas pada bagian hulu merupakan debit rancangan dari HSS gama I dan pada bagian hilir adalah normal depth dengan nilai slope sebesar 0.005 . hasil simulasi menunjukan bahwa pada sebagian besar bantaran Sungai Sibinail pada kala ulang 2 tahun sudah terjadi genangan banjir dengan nilai kedalaman ekstrem sebesar $2.57 \mathrm{~m}$.
\end{abstract}

Kata Kunci Sungai Sibinail,Simulasi Profil Muka Air, HEC-RAS

\begin{abstract}
Sibinail River in Pasaman Regency is one of the rivers prone to floods. To overcome the flooding problem, information is needed about the depth of the flood and the points where the location is prone to flooding. Therefore simulating a water level profile aims to provide information about the depth of floods and flood-prone points on the Sibinail River in Pasaman Regency. Water level profile simulation modeling uses HEC-RAS software. The design flood discharge is calculated with a return period of 2 years, 5 years, 10 years, 25 years and 50 years using the gamma synthetic unit (HSS) hydrograph. The boundary condition in the upstream part is the design discharge from HSS gama I and in the downstream part is the normal depth with a slope value of 0.005 . The simulation results show that in most parts of the Sibinail River at the time of the return of 2 years there has been a flood inundation with an extreme depth of $2.57 \mathrm{~m}$.
\end{abstract}

Keywords: Sibinail River, Water level profile simulation, HEC-RAS

\section{PENDAHULUAN}

Kondisi ikilm pada DAS Sibinail yang memiliki curah hujan yang cukup tinggi sering mengakibatkan terjadinya banjir. Banjir yang sering terjadi mengakibatkan kerugian secara ekonomi maupun sosial bagi masyarakat sekitar yang tinggal di bantaran Sungai Sibinail. Selain faktor curah hujan banjir yang terjadi di Sungai Sibinail juga dipengaruhi kondisi penampang sungai yang kurang baik. Oleh karena itu perlu dilakukan analisis mengenai banjir pada Sungai Sibinail guna memberikan penanganan yang tepat secara teknis untuk mengatasi masalah banjir pada Sungai Sibinail. Informasi mengenai titik rawan banjir sangat diperlukan guna memberikan penangan yang tepat secara teknis. Dengan melakukan simulasi profil muka air informasi mengenai titik-titik genangan banjir akibat debit banjir berdasarkan kala ulang tertentu dapat diperoleh.
Pada penelitian ini dilakukan simulasi profil muka air menggunakan HEC-RAS. Hasil simulasi menggunakan $H E C-R A S$ sangat diperlukan guna memberikan informasi titik rawan banjir agar mampu memberikan gambaran untuk dilakukan penanganan banjir pada Sungai Sibinail. Berdasarkan penelitian Riandi (2018) pada simulasi profil muka air Sungai Petai di Kota Bangkinang menunjukan penggunaan HEC-RAS mampu menyajikan informasi mengenai luapan genangan banjir pada Sungai Petai di Kota Bangkinang.

$H E C-R A S$ dalam penggunaanya memerlukan suatu data bentuk alur sungai dan data penampang sungai hasil pengukuran topografi. Dari hasil pengukuran tersebut dapat melihat bagaimana kondisi penampang yang dialiri oleh suatu debit banjir rancangan. Jika suatu penampang tidak mampu menampung besarnya debit rancangan maka akan terjadi luapan banjir. Luapan banjir yang menimbulkan kerugian bagi masyarakat sudah 
selayaknya medapatkan penanganan. Melalui informasi titik genangan banjir yang akan diperoleh dari hasil simulasi profil muka air diharapkan mampu memberikan gambaran untuk dilakukannya penangan yang tepat.

\section{TINJAUAN PUSTAKA}

\section{Daerah Aliran Sungai}

Daerah Aliran Sungai (DAS) adalah suatu kesatuan wilayah tata air yang terbentuk secara alamiah, dimana semua air hujan yang jatuh ke daerah ini akan mengalir melalui sungai dan anak sungai yang bersangkutan (Koedotie, 2013). DAS merupakan daerah yang dibatasi oleh punggungpunggung pegunungan dimana air hujan yang jatuh di daerah tersebut akan mengalir menuju sungai utama pada suatu titik/stasiun yang ditinjau (Triatmodjo, 2010).

\section{Digital Elevation Model (DEM)}

Model elevasi digital yang akan digunakan dalam penelitian yaitu Digital Elevation Model (DEM) ataupun Digital Terrain Model. Data DEM yang biasa digunakan pada penelitian sejenis adalah ASTER GDEM (Global Digital Elevation Model). Berdasarkan Penelitan Iqbal (2015) data DEM diolah menggunakan Perangkat Lunak GIS dengan cara mendelineasi berdasarkan batas alami DAS.

Pada penelitian ini data yang digunakan adalah $D E M$ Nasional yang diperoleh melalui alamat tides.big.go.id/DEMNAS/. DEM Nasional dibangun dari beberapa sumber data meliputi data IFSAR (resolusi $5 \mathrm{~m}$ ) TERRASAR-X (resolusi $5 \mathrm{~m}$ ) dan ALOS PALSAR (resolusi 11,25 m) dengan menambahkan data masspoint hasil stereo-plotting. Resolusi spasial DEM Nasional adalah 0,27arcsecond, dengan menggunakan datum vertikal EGM2008.

\section{Data Curah Hujan}

Intensitas hujan tinggi pada umumnya terjadi dalam durasi yang pendek dan mencakupi daerah yang tidak luas. Faktor utama terjadinya banjir adalah hujan deras yang turun di Daerah Aliran Sungai (DAS). Hal ini disebabkan curah hujan yang tinggi akan memberikan sumbangan debit air yang lebih besar ke DAS dan apabila daya tampung DAS terlampaui atau melebihi kapasitas maka akan menimbulkan banjir (Loebis, 1992 dalam Suhardiman, 2012).

Seri data hujan yang diperoleh dari pos penangkar hujan atau stasiun hujan digunakan untuk menganalisis frekuensi data curah hujan. Menurut (Harto,1993 dalam Hidayat,2008), ada 2 (dua) cara yang dapat digunakan dalam penetapan analisis seri data, yaitu sebagai berikut.

1. Cara pertama, dengan mengambil satu data maksimum tiap tahun, yang berarti jumlah data dalam seri akan sama dengan panjang data yang tersedia. Maka hanya besaran maksimum tiap tahun saja yang berpengaruh dalam analisis selanjutnya. Seri data ini dikenal dengan "maximum annual series".

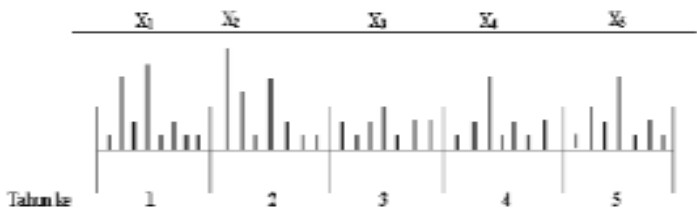

Gambar 1. Seri Hujan Maksimum Tahunan

2. Cara kedua,dengan partial series. Cara ini menetapkan suatu batas tertentu (threshold). Selanjutnya semua besaran hujan/debit yang lebih besar daripada batas bawah tersebut diambil dan dijadikan bagian seri data untuk dianalisis dengan cara-cara yang lazim.

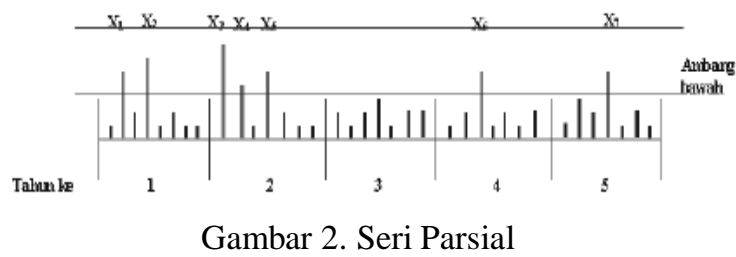

\section{Jenis Distribusi Frekuensi}

Dalam statistik dikenal beberapa jenis distribusi frekuensi dan yang biasa digunakan dalam hidrologi yaitu :
a. Distribusi Normal
b. Distribusi Log Normal
c. Distribusi Log-Person Type III
d. Distribusi Gumbel

\section{Analisis Debit Banjir Rencana Menggunakan Hidrograf Satuan}

Debit banjir rencana adalah debit yang dipakai dalam perhitungan perencanaan pengendalian banjir dan dinyatakan berdasarkan kala ulang tertentu. Besarnya kala ulang mempertimbangkan faktor keamanan tertentu, serta kelayakan teknis dan lingkungan. Perhitungan besarnya debit rencana dapat ditentukan dengan hidrograf satuan.

Hidrograf satuan merupakan hidrograf limpasan langsung akibat dari hujan efektif yang terjadi merata di seluruh DAS dengan intensitas tetap dalam satuan waktu yang ditetapkan (Sherman, 1932, dalam Harto, 1993). Hidrograf dapat digambarkan sebagai penyajian antara unsur aliran dan waktu (Harto,1993). DAS dipandang sebagai blok yang sistemnya ditandai oleh respon $\mathrm{Q}$ input tertentu, sebagai berikut:

a. Input nyata, yaitu hujan efektif

b. Proses merupakan kombinasi dari karakteristik hujan seperti : tipe, intensitas, durasi dan distribusi hujan, defisit kelembaban tanah, 
kondisi iklim, serta karakteristik DAS seperti : ukuran DAS, bentuk DAS, Elevasi DAS, rerata kemiringan sungai, kerapatan sungai, kerapatan drainase, susunan sistem sungai, jenis tanah, dan jenis vegetasi penutup.

c. Respons (output) yaitu setiap DAS mempunyai karakteristik hujan dan kondisi fisik yang berbeda, sehingga setiap hidrograf di setiap DAS, mempunyai komponen hidrograf yang berbeda. Secara Skema sistem hidrograf satuan dapat dilihat pada Gambar 3.
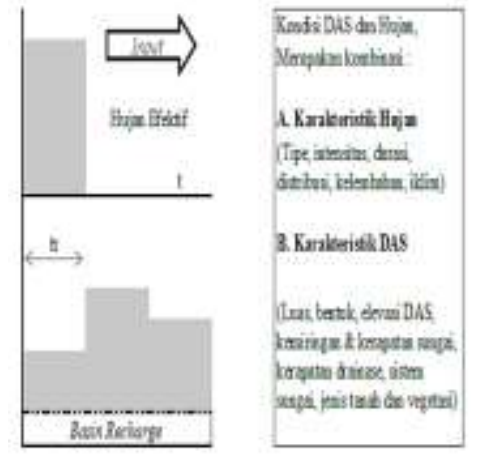

PRoses

Gambar 3. Sistem Hidrograf Satuan

\section{Hidrograf Satuan Sintetik Gama I}

Menurut (Harto,1985 dalam Nadia, 2016) dengan memperhatikan tanggapan sungai-sungai di Pulau Jawa terhadap masukan hujan maka dipandang sangat memadai dengan menyajikan sisi naik hidrograf satuan sebagai garis lurus (linier) (Gambar 4). Adapun sisi resesi (recession limb) hidrograf satuan disajikan dengan persamaan eksponensial sebagai berikut:

$\mathrm{Qt}=\mathrm{Qpe}^{-(\mathrm{t}-\mathrm{Tr}) / \mathrm{k}}$

dengan :

$\mathrm{Q}_{\mathrm{t}}=$ debit yang di ukur pada jam ke-t sesudah debit puncak $\left(\mathrm{m}^{3} / \mathrm{dt}\right)$,

$\mathrm{QP}=\operatorname{debit}$ puncak $(\mathrm{m} 3 / \mathrm{dt})$,

$\mathrm{t}=$ waktu yang diukur dari saat terjadinya debit puncak (jam),

$\mathrm{k}=$ koefisien tampungan (jam).

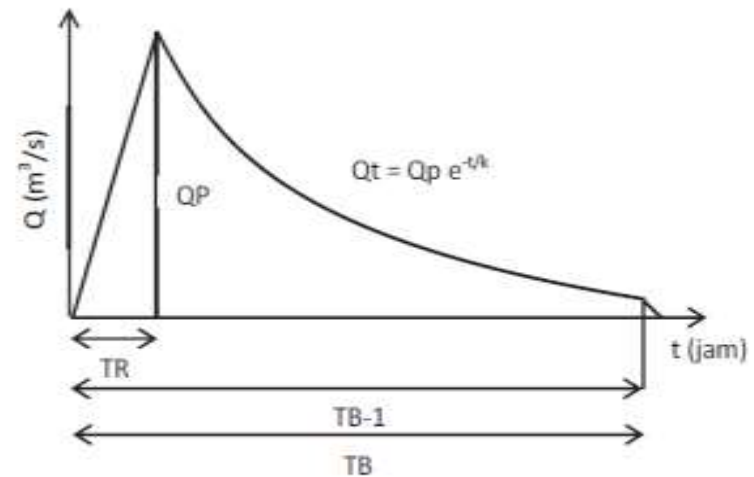

Gambar 4. Sketsa hidrograf satuan sintetik Gama I
Model (Hydrologic Engineering Center - River Analysis System) HEC-RAS

Penggunaan Model HEC-RAS dimaksudkan untuk mengetahui kapasitas alur dan profil muka air sungai terhadap banjir dengan kala ulang tertentu, sehingga dapat diketahui tinggi muka air maksimum yang terjadi di sepanjang sungai yang ditinjau. HECRAS memiliki empat komponen model satu dimensi:

a. hitungan profil muka air aliran permanen,

b. simulasi aliran tak permanen,

c. hitungan transpor sedimen, dan

d. hitungan kualitas air

\section{METODE PENELITIAN}

\section{Lokasi Penelitian}

Lokasi penelitian dilakukan pada Daerah Aliran Sungai Sibinail yang berada di Kabupaten Pasaman Provinsi Sumatera Barat. Hulu Sungai Batang Sibinail berada di Kecamatan Rao dan bermuara di Sungai Batang Asik Kecamatan Rao Selatan.

\section{Data Penelitian}

Data penelitian terdiri dari data hidrologi dan data geometri. Data hidrologi berupa data curah hujan maksimum yang diperoleh dari stasiun hujan paling dekat dengan lokasi penelitian. Sedangkan untuk data geometri berupa data hasil pengukuran geometri penampang sunga hasil pengukuran topografi dan data elevasi digital berupa data DEM untuk membuat batas Daerah Aliran Sungai (DAS).

\section{Prosedur Penelitian}

Prosedur penelitian terdiri dari beberapa tahapan. Tahapan pertama berupa analisis hidrologi untuk memperoleh debit banjir rencana. Tahap kedua berupa pemodelan penampang sungai menggukan HEC-RAS dan HEC-GeoRAS lalu kemudian mengimput debit banjir rencana untuk dilakukan simulasi. Tahap terakhir melakukan analisis terhadap hasil simulai profil muka air. 


\section{Diagram Penelitian}

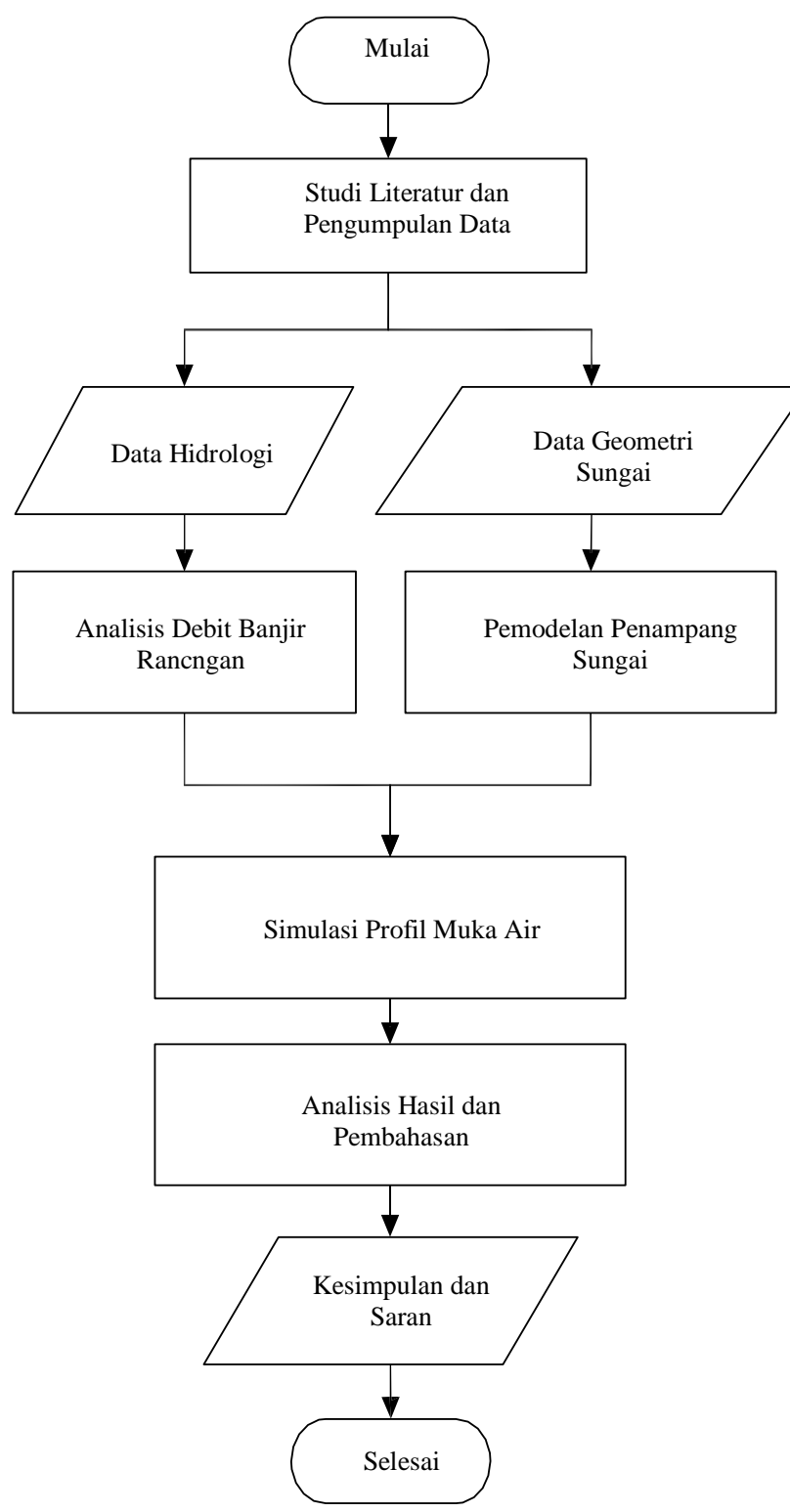

Gambar 6. Sketsa hidrograf satuan sintetik Gama I

\section{HASIL DAN PEMBAHASAN}

\section{Data Curah Hujan}

Nilai curah hujan yang diperoleh dari Stasiun Rao digunakan sebagai dasar untuk menganalisis curah hujan. Nilai hujan yang diambil adalah seri hujan maksimum pada tiap tahunnya seperti pada Gambar 7.

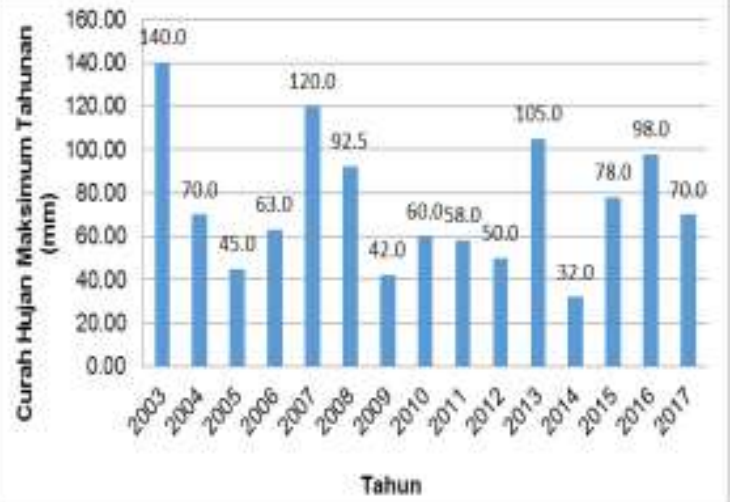

Gambar 7. Nilai curah hujan maksimum tahunan pada stasiun rao

\section{Analisis Debit Banjir Rancangan}

Dari data curah hujan diatas dilakuan anlisis frekuensi dengan distribusi log perason tipe III untuk mendapatkan curah hujan kala ulang 2,5,10,25 dan 50 tahun. Kemudian dari nilai curah hujan dengan kala ulang yang disebutkan dilakukan perhitungan intensitas hujan jam-jaman dengan rumus mononobe.

Dengan melakukan analisis perhitungan menggunkan hidrograf satuan sintetik (HSS) gama I diperoleh nilai debit puncak debit yang akan digunakan sebagai debit banjir rancangan seperti pada tabel 1 .

Tabel 1. Rekapitulasi nilai debit puncak sungai sibinail

\begin{tabular}{|c|c|c|c|c|c|}
\hline $\begin{array}{c}\text { Debit } \\
\text { Puncak } \\
(\mathrm{m} 3 / \mathrm{dt})\end{array}$ & Q2 & Q5 & Q10 & Q25 & Q50 \\
\cline { 2 - 6 } & 124.6 & 156.2 & 205.1 & 242.4 \\
\hline
\end{tabular}

\section{Pemodelan Alur Sungai dan Penampang Sungai Pada HEC-RAS}

Pemodelan alur sungai pada HEC-RAS berdasarkan data pengukuran topografi di lapangan dimana data alur sungai dari hulu ke hilir didigitasi pada HEC-RAS kemudian memasukan data penampang melintang pada jendela cross section seperti yang ditunjukan pada Gambar 8 dan Gambar 9.

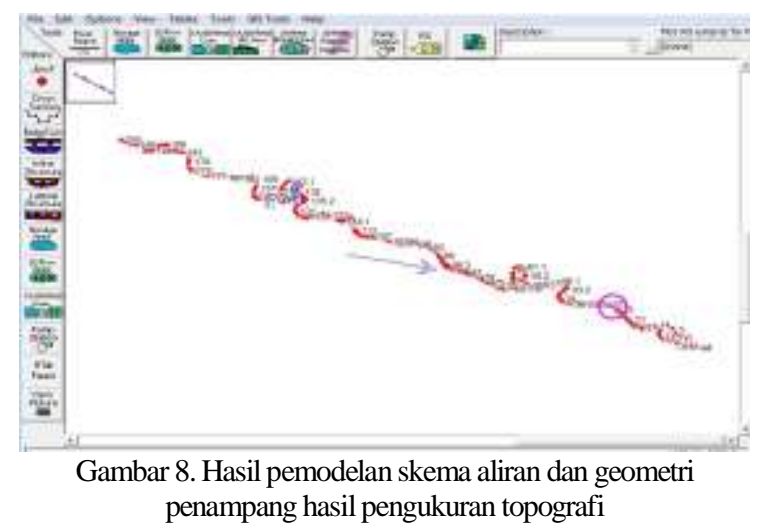




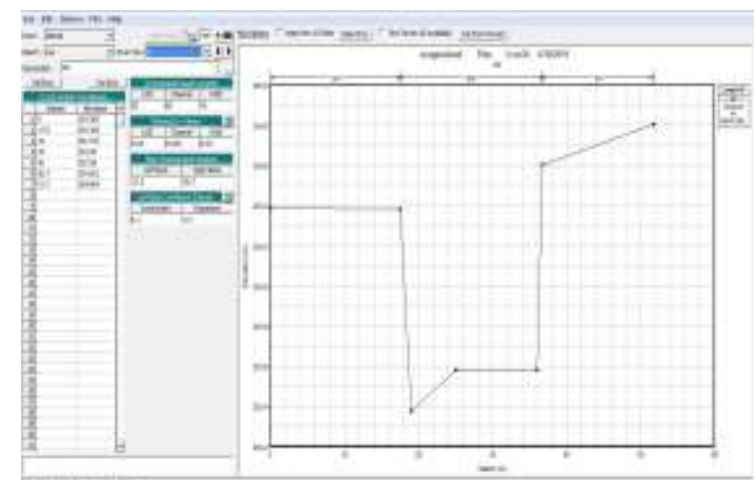

Gambar 9. Tampilan jendela cross section data

\section{Memasukan nilai koefisien manning}

Setelah pembuatan pemodelan penampang kemudian langkah selanjutnya adalah memasukan nilai koefisien manning penampang. Pada penelitian ini nilai manning pada kanal sungai yaitu sebesar 0.035 sedangkan pada bank sungai nilai manning sebesar 0.04 .

\section{Pemasukan Data Debit Rancangan}

Selanjutnya pemasukan data debit yang diperoleh dari analisis hidrologi debit banjir rencana. Terdapat 5 profil debit yaitu Q2, Q5, Q10, Q25, dan Q50. Untuk memudahkan pemasukan data, nama profil debit diubah sesuai debit kala ulang. Cara pemasukan data debit pada HEC-RAS dapat dilihat pada Gambar 10.

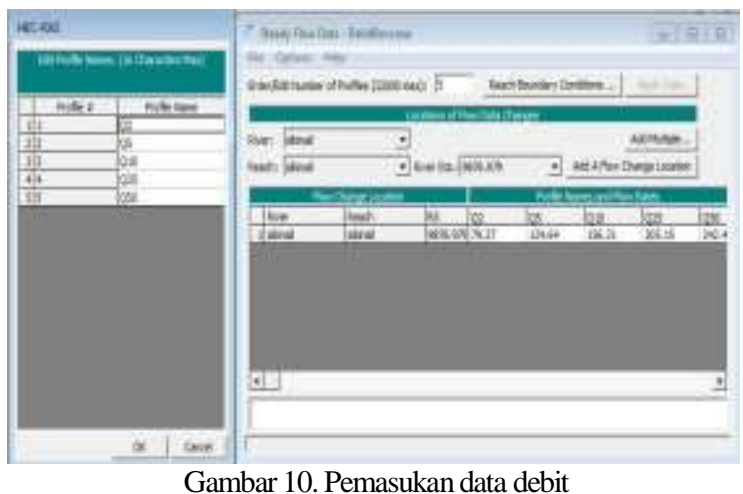

Proses selanjutnya adalah menentukan kondisi batas pada aliran permanen kondisi batas yang dipilih adalah pada hilir sungai. Kondisi batas yang digunakan adalah normal depth dengan nilai slope 0.05 . adapun cara pemasukan nilai kondisi batas dapat dilihat pada Gambar 11.

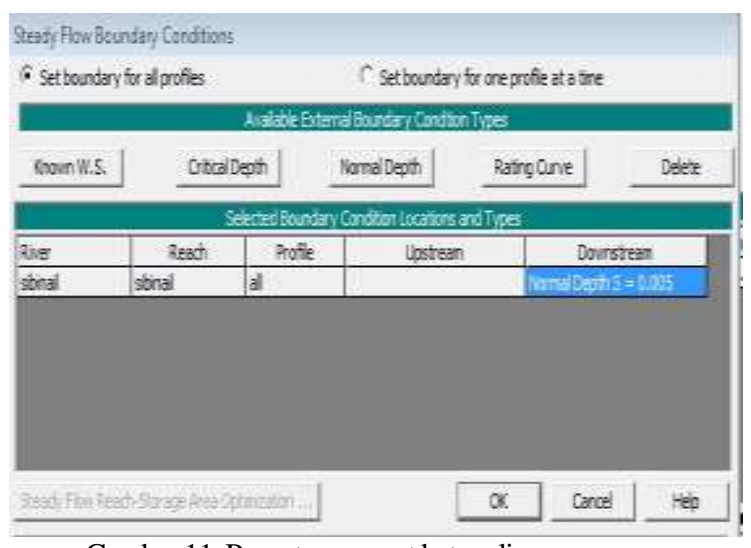

Gambar 11. Penentuan syarat batas aliran permanen

\section{Komputasi Aliran Permanen}

Sebelum melakukan komputasi aliran permanen, terlebih dahulu membuat plan beserta kode identifikasi yang unik untuk plan yang dibuat dari menu Steady Flow Analysis. Selanjutnya menentukan berkas geometri (Geometry File) dan berkas data debit aliran (Steady Flow File) yang telah dibuat sebelumnya. Selanjutnya menetapkan tipe aliran yaitu subkritis dan mengaktifkan opsi Floodplain Mapping. Kemudian melakukan komputasi aliran permanen dengan mengklik tombol Compute. Tahapan dari komputasi aliran permanen ini dapat dilihat pada Gambar 12 dan Gambar 13.

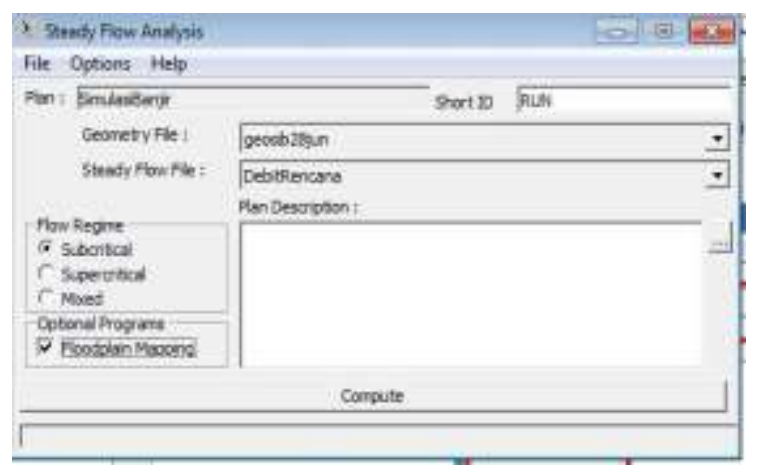

Gambar 12. Persiapan Komponen Komputasi Aliran Permanen

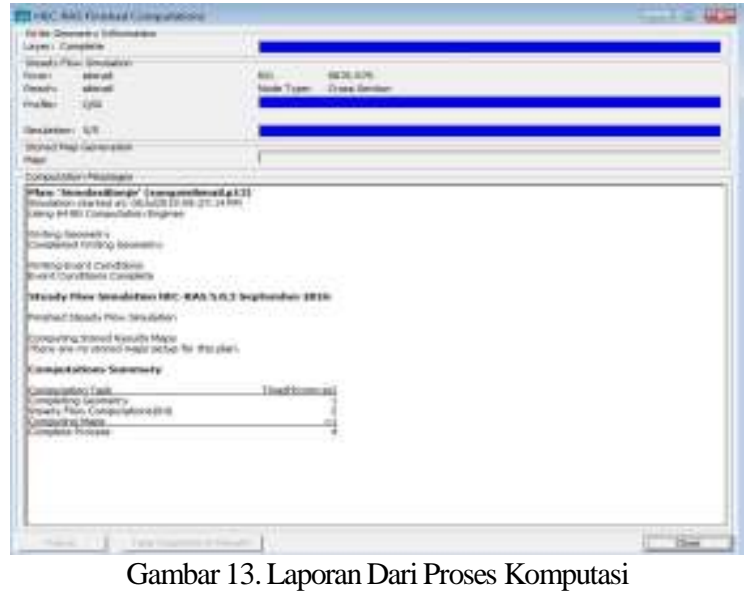




\section{Hasil Simulasi Profil Muka Air}

Hasil simulasi menunjukan bahwa genang banjir terjadi pada setiap profil debit rancangan. Dari pembacaan tabel dan grafik pada nilai kedalaman banjir yang dapat dilihat pada $H E C-R A S$ diperoleh nilai kedalaman ekstrem pada tiap debit kala ulang adalah sebagai berikut.

Tabel 2 Nilai kedalaman ekstrem genangan banjir pada Sungai Sibinail

\begin{tabular}{|c|c|c|}
\hline Nama Sungai & $\begin{array}{c}\text { Debit Kala } \\
\text { Ulang }\end{array}$ & $\begin{array}{c}\text { Kedalaman ekstrem } \\
(\mathrm{m})\end{array}$ \\
\hline \multirow{4}{*}{$\begin{array}{c}\text { Sungai } \\
\text { Sibinail }\end{array}$} & Q2 & 2.57 \\
\cline { 2 - 3 } & Q5 & 2.94 \\
\cline { 2 - 3 } & Q10 & 3.14 \\
\cline { 2 - 3 } & Q25 & 3.41 \\
\cline { 2 - 3 } & Q50 & 3.59 \\
\hline
\end{tabular}

(Sumber : analisis 2019)

Kedalaman ekstrem terjadi pada sta 2500 pada bagian sebelah kanan jika dilihat dari hulu sungai. Dimana air sungai meluap diakbatkan kondisi penampang yang tidak cukup baik dalam menampung debit banjir yang cukup besar seperti yang ditunjukan pada Gambar 14 sampai Gambar 18

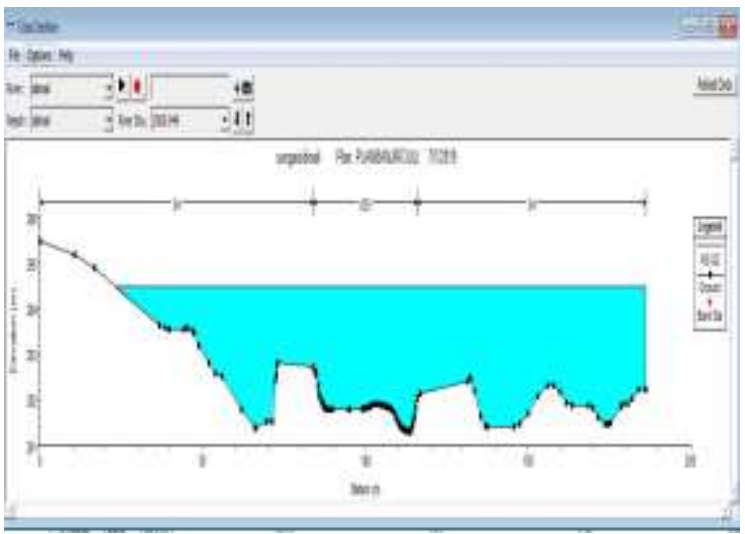

Gambar 14. Kedalaman Kritis Pada Q2

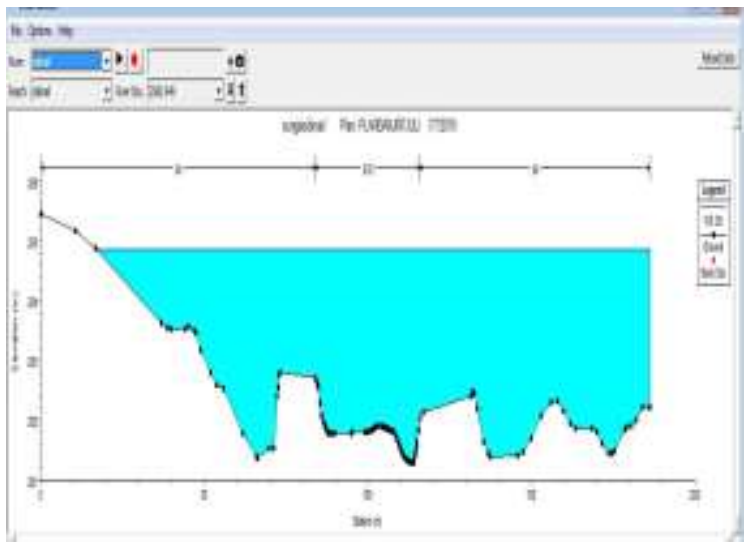

Gambar 15. Kedalaman Kritis Pada Q5

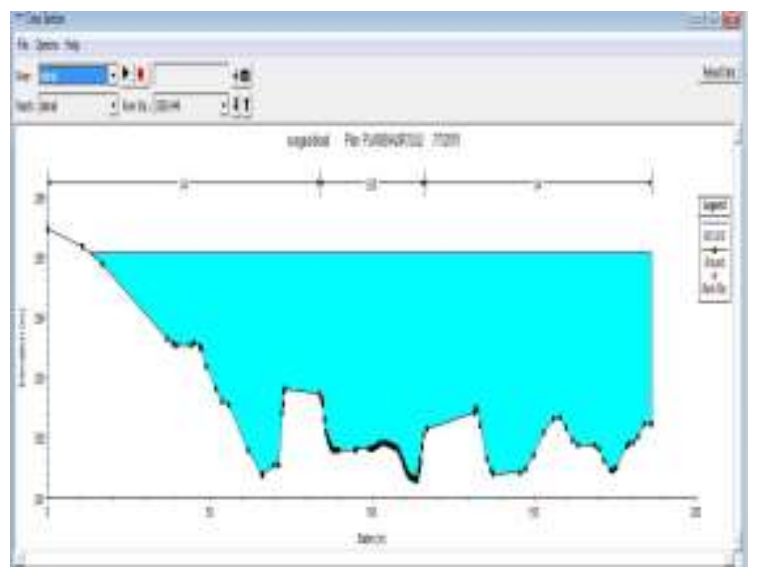

Gambar 16. Kedalaman Kritis Pada Q10

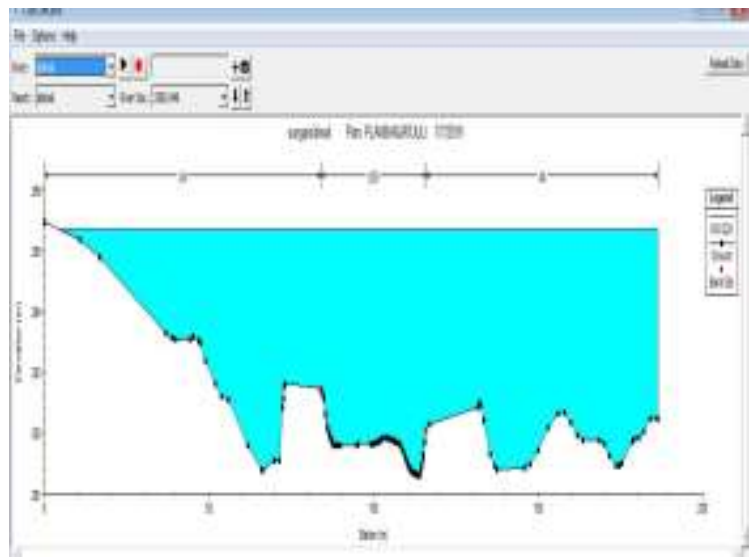

Gambar 17. Kedalaman Kritis Pada Q25

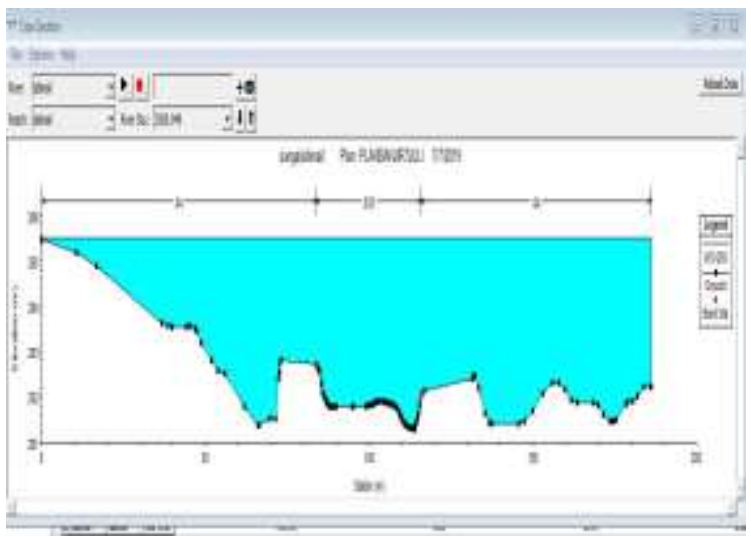

Gambar 18. Kedalaman Kritis Pada Q50

Dapat dilihat pada profil memanjang sungai pada tiap-tiap kala ulang yang di tunjukan pada Gambar 19 sampai Gambar 23 pada bagian hilir sungai rata-rata hampir seluruhnya terjadi genangan banjir. 


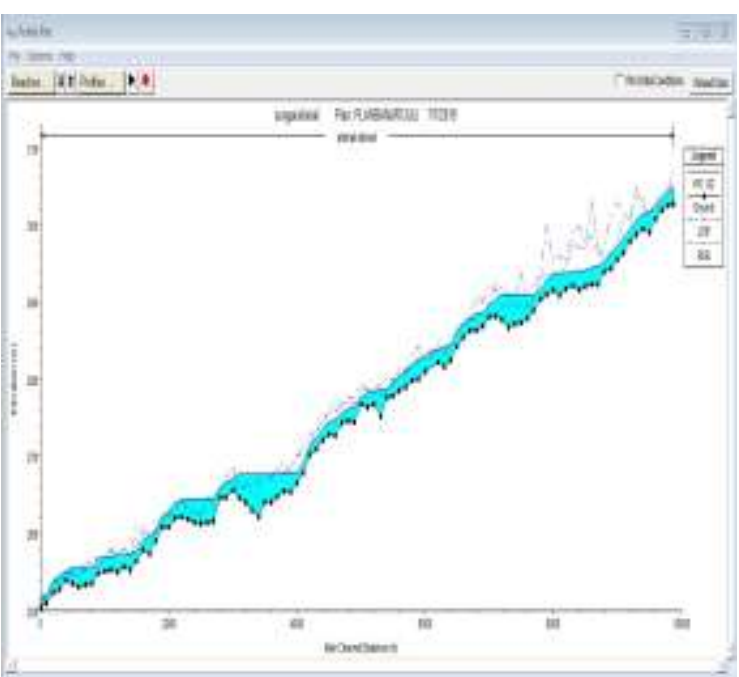

Gambar 19. Profil memanjang sungai sibinail pada Q2

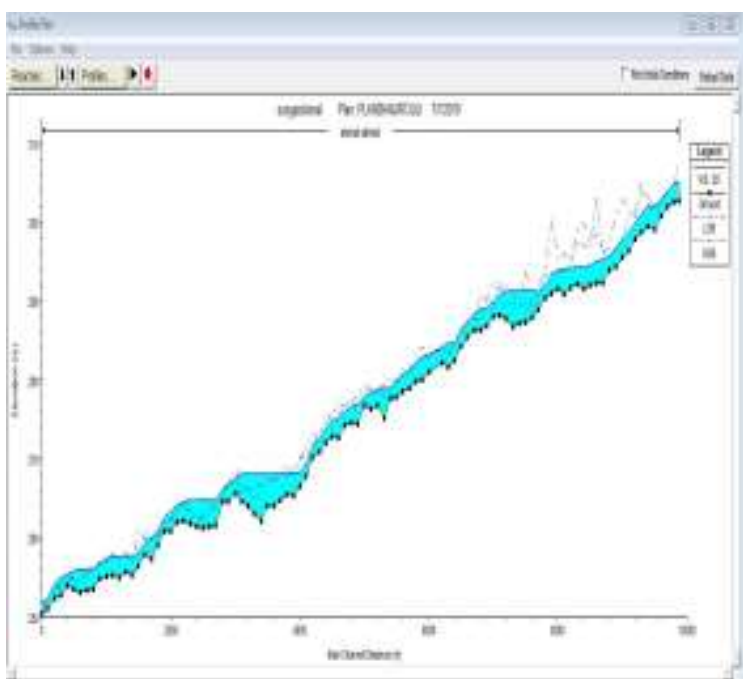

Gambar 20. Profil memanjang sungai sibinail pada Q5

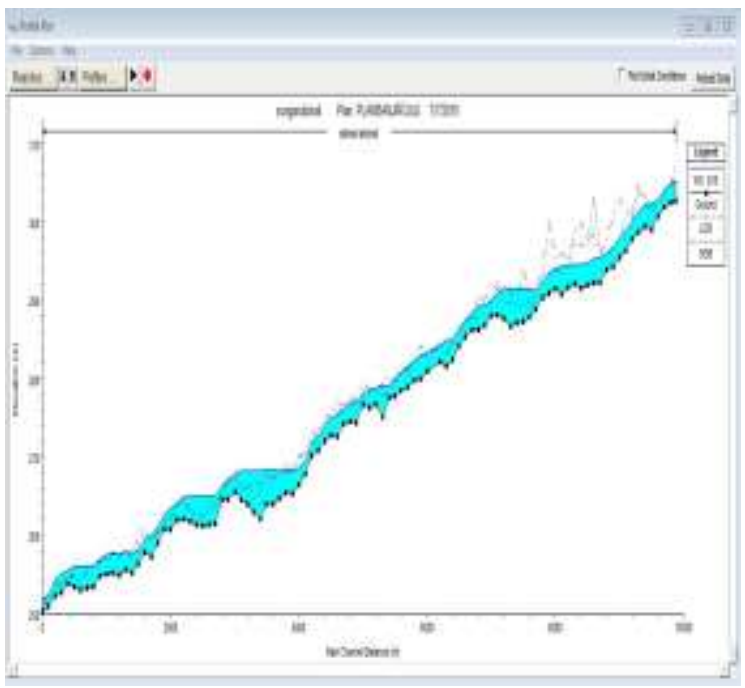

Gambar 21. Profil memanjang sungai sibinail pada Q10

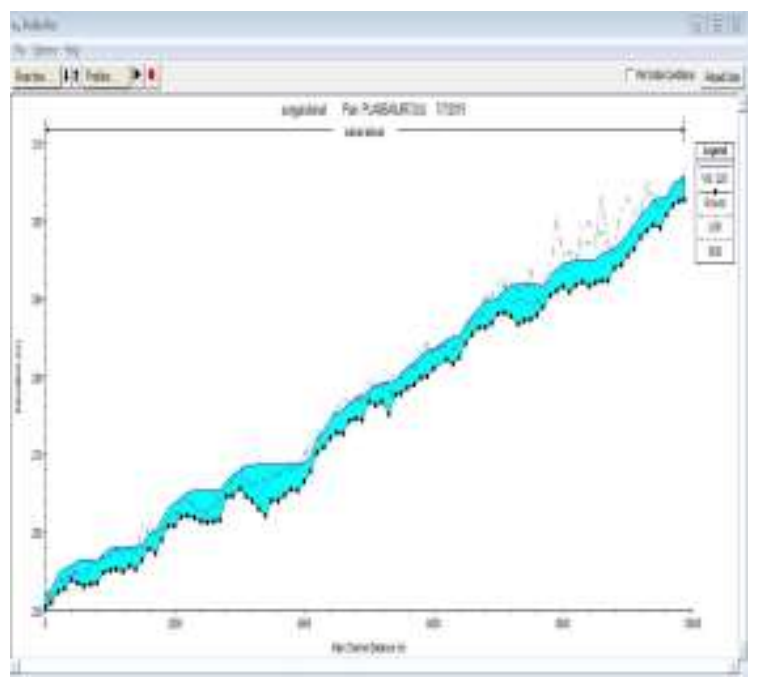

Gambar 22. Profil memanjang sungai sibinail pada Q25

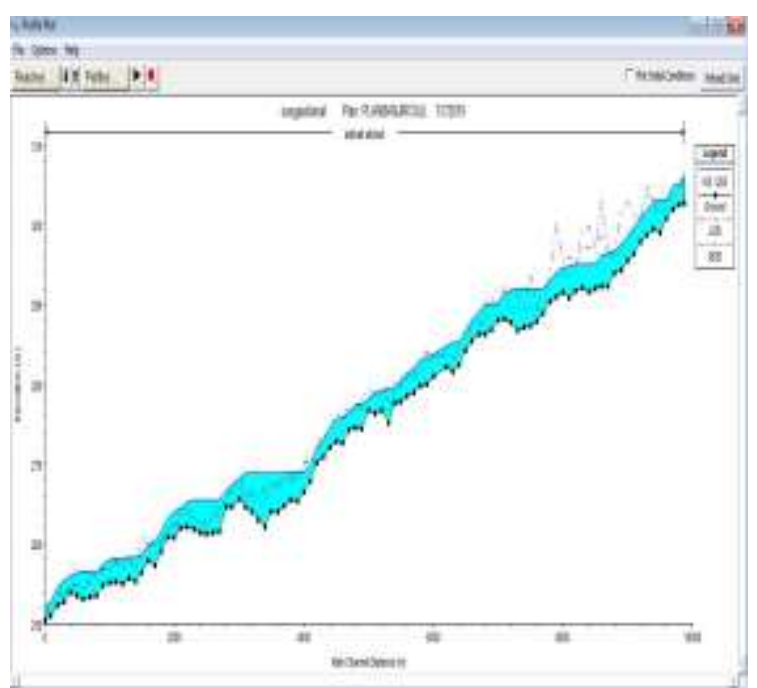

Gambar 23. Profil memanjang sungai sibinail pada Q50

\section{KESIMPULAN}

Dari hasil simulasi profil muka air dapat disimpulkan titik rawan banjir paling banyak berada pada daerah hilir sungai sibinail. Hal ini ditunjukan bahwa dari seluruh debit kala ulang hampir seluruhnya bagian hilir tergenang oleh genangan banjir.

Nilai kedalaman ekstrem pada debit kala ulang 2 tahun sebesar 2.57, kala ulang 5 tahun sebesar 2.94, kala ulang 10 tahun sebesar 3.14, kala ulang 25 tahun sebesar 3.41 dan kala ulang 50 tahun sebesar 3.59. untuk nilai kedalaman ekstrem ini berada pada sta 2500 dari hilir sungai sibinail.

\section{DAFTAR PUSTAKA}

[1] Harto, S. 1993. Analisis Hidrologi. Jakarta: Gramedia Pustaka Utama

[2] Hidayat,T. 2008. Analisa Kurva Massa Sebagai Alternatif Pengendalian Banjir Genangan. Skripsi Program Sarjana Teknik Sipil. Pekanbaru: Universitas Riau 
[3] Iqbal, M., 2015. Analisis Pengaruh Perubahan Tata Guna Lahan Terhadap Ketersedian Air Di Daerah Aliran Sungai (Das) Siak, Provinsi Riau. Pekanbaru: Universitas Riau.

[4] Koedotie, R. J.,2013. Rekayasa dan manajemen Banjir kota. Yogyakarta: Andi.

[5] Nadia, F. 2016. Analisis Karakteristik DAS Di Kota Pekanbaru Berbasis Sistem Informasi Geografis Untuk Menganalisis Hidrograf Satuan Sintetik. Pekanbaru: Universitas Riau.

[6] Riandi, D., 2018. Simulasi Profil Muka Air Sungai Petai Untuk Pemetaan Genangan Akibat Banjir Di Kota Bangkinang. Pekanbaru: Universitas Riau.

[7] Suhardiman. 2012. Zonasi Tingkat Kerawanan Banjir Dengan Sistem Informasi Geografis (SIG) Pada Sub Das Walanae Hilir. Skripsi Sarjana Jurusan Teknologi Pertanian. Makassar: Universitas Hasanuddin.

[8] Triadmojo, B., 2010. Hidrologi Terapan. 2 ed. Yogyakarta: Betha offset. 